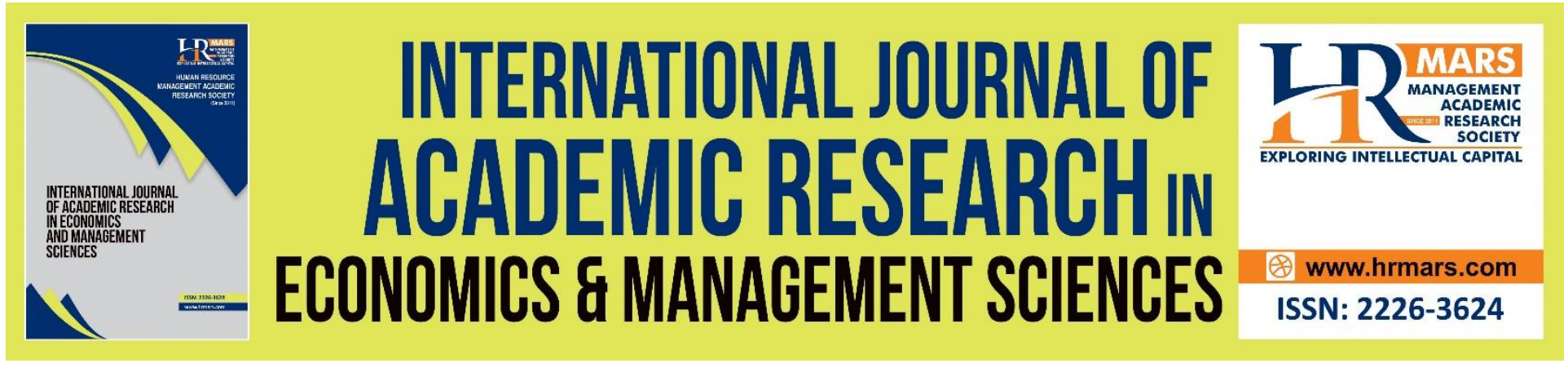

\title{
The Knowledge-Based Economic Drivers in Arabic Gulf Countries
}

Kamarudin Othman, Syahrul Nadwani Abdul Rahman, Wan Adibah Wan Ismail, Yanti Aspha Ameira Mustapha

To Link this Article: http://dx.doi.org/10.6007/IJAREMS/v10-i3/11285 DOI:10.6007/IJAREMS/v10-i3/11285

Received: 05 July 2021, Revised: 10 August 2021, Accepted: 06 September 2021

Published Online: 28 September 2021

In-Text Citation: (Othman et al., 2021)

To Cite this Article: Othman, K., Rahman, S. N. A., Ismail, W. A. W., \& Mustapha, Y. A. A. (2021). The KnowledgeBased Economic Drivers in Arabic Gulf Countries. International Journal of Academic Research in Economics and Management and Sciences, 10(3), 375-382.

Copyright: (c) 2021 The Author(s)

Published by Human Resource Management Academic Research Society (www.hrmars.com)

This article is published under the Creative Commons Attribution (CC BY 4.0) license. Anyone may reproduce, distribute, translate and create derivative works of this article (for both commercial and non-commercial purposes), subject to full attribution to the original publication and authors. The full terms of this license may be seen at: http://creativecommons.org/licences/by/4.0/legalcode

Vol. 10, No. 3, 2021, Pg. 375 - 382

Full Terms \& Conditions of access and use can be found at http://hrmars.com/index.php/pages/detail/publication-ethics 


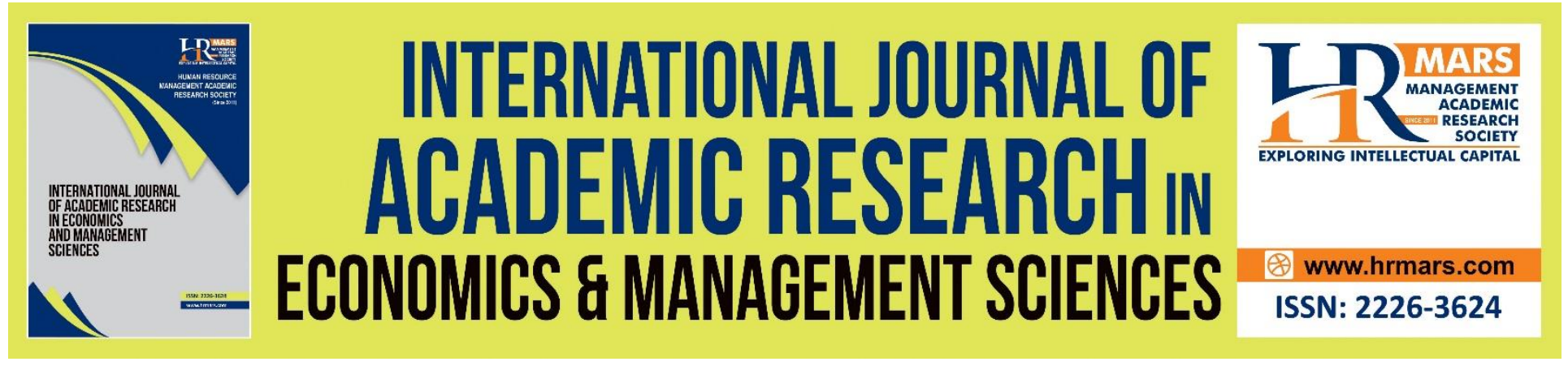

\title{
The Knowledge-Based Economic Drivers in Arabic Gulf Countries
}

\author{
Kamarudin Othman ${ }^{1}$, Syahrul Nadwani Abdul Rahman², Wan \\ Adibah Wan Ismail ${ }^{3}$, Yanti Aspha Ameira Mustapha ${ }^{4}$ \\ 1,2,4 Senior lecturer, Faculty of Business and Management, Universiti Teknologi Mara, Kedah, \\ Malaysia, ${ }^{3}$ Associate professor, Faculty of Accountancy, Universiti Teknologi Mara, Kedah, \\ Malaysia. \\ Email: wadibah@uitm.edu.my
}

\begin{abstract}
Over the past ten years, Arab Gulf countries have made it an explicit aim to transform their economies into a knowledge-based economy. Now the knowledge economies have expanded and become more essential for Arab Gulf states. It had become a strategic vision and plans for economic diversification. This paper aims to analyse the impact of knowledge-based economy on economic development in Arabic Gulf countries over the 1980-2015 period. This study employed a wide variety of dimensional index approach to a knowledge-based economy. The data allowed us to evaluate the impact of knowledge on economic growth extensively. Panel time series method was employed to analyse the role of knowledge-based economy on economic development, using the long-run FLOMS, DOLS and PMG regression analysis. This study found that three knowledge-based economy criteria, education, information and communication technology (ICT) and innovation, significantly influence Arabic Gulf countries' economic growth. The findings are useful for the regulators in the Gulf countries as input for their effort to create an economic environment conducive to enhancing the level of knowledge and, hence, economic growth.
\end{abstract}

Keywords: Knowledge-Based Economic, Economic Development, Arabic Gulf Countries, Panel Time Series.

\section{Introduction}

A knowledge-based economy is a system of consumption and production based on intellectual capital. It refers to the ability to leverage scientific findings and applied research. The knowledge-based economy provides enormous benefit for most developed countries. Adopting a knowledge-oriented economy is seen as the path to overcome societal deficiencies caused by urbanisation, such as uneven development, social inequalities in cities and urban regions, and environmental degradation (Yigitcanlar, Guaralda, Taboada, \& Pancholi, 2016). In a knowledge-based economy, significant value components may contain intangible assets such as the value of their employees or intellectual property (Carrillo, 2015; Volkov \& Garanina, 2007). In addition, it also became the primary engine of economic growth (Barkhordari et al., 2019; Tamtana, 2007). Thus, the knowledge-based economy is an 
economic element where the generation and utilisation of knowledge contribute significantly to economic growth and wealth creation (Ogundeinde \& Ejohwomu, 2016; World Bank, 2015).

Numerous countries have begun to realise the importance of the knowledge economy to national development (Wan Ismail et al., 2012). The Arab region also noticed it, and they took several steps to move along with the changes. Generally, the Arab region is now making a major conversion, which focuses on transforming their political, social and economic sectors (World Bank, 2015). In the economic sector, the focus of transformation to execute the knowledge economy as a pillar of economic growth. This is important because most of the Arab countries are being recognised as medium-income countries. Currently, seventeen of the twenty-two countries in the Arab region have adopted economic development based on knowledge as short and long term policy (Schwalje, 2014). If this is successful, it will positively impact the economic growth of the Arab region.

The main question is the readiness of the Arab countries to meet the challenges of providing knowledgeable, high-level human capital and professional energy to move towards the knowledge economy. To answer this question, this research analyses the current level of implementation of the knowledge-based economy using several criteria and dimensions that are perceived to describe the intensity of knowledge-based application.

The efforts of the gulf countries to disclose the knowledge economy has begun over the past ten years. The concept of the knowledge economy has become an essential role in the strategic vision of the gulf countries in the plan for economic diversity (Hvidt, 2015). However, despite the importance and popularity of the knowledge economy, it remains a vague term for the Arabs. This has made this plan difficult for the Arab Gulf nations to accelerate development based on the knowledge economy. According to the World Bank (2015), as shown in Figure 1, the Arabic Gulf countries' position was ranked between 42 and 64 on a knowledge-based economic index. This position is below the aggregate score for Europe and Central Asia. Nevertheless, it is still above the world average.

Figure 1:

Knowledge Economy Index 2012 and Ranking For Selected Arabic Gulf Countries

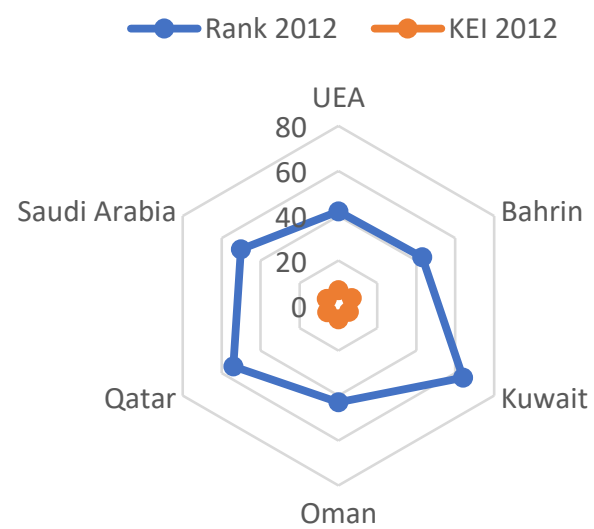

Source: Knowledge Assessment Methodology (www.worldbank.org/kam, World Bank, 2012). The country's economic growth is highly dependent on the country's strength to face the knowledge-based economic challenges (Ogundeinde \& Ejohwomu, 2016). Among the challenges faced by Arab countries are the poor status of knowledge indictors, poor knowledge-based economy and the limited role of knowledge (El-Khoury, 2015; Nour, 2019). 
this makes the Arab countries underperform in terms of the knowledge-based economy compared to other developed and emerging countries. (Ryan \& Daly, 2019). Moreover, it is not an easy task for the Arab countries to transform into a knowledge economy because a successful knowledge economy rests on an intricate relationship between entrepreneurship, motivation, enabling economic and institutional regimes (Hvidt, 2015). This situation requires additional attention from the Arabic government to emphasise the role of a knowledge-based economy on national development.

Thus, this study aims to investigate the contribution of the knowledge-based economy to the economic growth of Arabic Gulf countries. This paper is organised as follows. Section 2 provides the literature review about the overview of the knowledge-based economy and critical factors that influence the knowledge-based economy. This is followed by Section 3 to analyse the data. Next, Section 4 presents the results of the data analysis and the discussion. Finally, this study concludes the findings and provides the future directions of the study in Section 5.

\section{Literature Review}

In the year 1966, Peter Druker introduced the concept of knowledge workers (Weber, 2011). The original concept of this idea is based on the knowledge and information concept. Since then, this concept has often been emphasised in economic activity transactions to information, technology and knowledge. In business, knowledge can change the landscape and help businesses run smoothly and faster than ever before (Kamarudin et al., 2012). This will help the business grow and create better economic conditions (Huarng, Rey-Martí, \& Guaita-Martínez, 2020). Furthermore, knowledge is a crucial driver of long-term economic development and a key source of competitiveness (Asongu \& Kuada, 2020; Rezny, White, \& Maresova, 2019).

Several studies have investigated the relationship of the critical factors between knowledgebased economies and national development in the Arab region (Asongu \& Andrés, 2020; Barkhordari et al., 2019; Ben Hassen, 2020; Schwalje, 2014; Weber, 2011). This will facilitate the process of creating a community that can enhance knowledge, creativity, and innovation and nurture the knowledgeable community. To explore the influence of a knowledge-based economy on economic development, this study will explore some of the critical factors in the Arab Gulf country. Based on the previous literature survey (Nour, 2019), critical factors that could influence economic developments are capital, skills, innovation and Information and Communication Technology (ICT).

Capital is one of the major compensator in economic growth apart from population growth and technological advancement (Todaro \& Smith, 2006). Capital investment is a long-term investment that allows the country to obtain revenue for the years ahead. Capital investments can be increased by intensifying the research and development (R\&D) activities of a country. Indirectly, the R\&D activities can ensure creation of efficient and productive human resources. Extant researches have argued that the growing capital structure will increase a country's economic growth (Booth et al., 2001; Mahmud, 2003; Mokhova \& Zinecker, 2014). Numerous studies conducted on some Arab countries also show that capital plays a vital role in their economic growth (Abu-Qarn \& Abu-Bader, 2007; Acikgoz \& Ben Ali, 2019; Malik \& Masood, 2021).

Investment in education has become one of the central policies in economic development (Marquez-Ramos \& Mourelle, 2019). Investment in education can produce a young generation that can fill jobs in the next century. Furthermore, through these educational 
investments, the country will be able to produce human capital that can assist in the economic growth of the country (Afzal et al., 2011; Marquez-Ramos \& Mourelle, 2019; Self \& Grabowski, 2004). Thus, all countries, including Arab countries, should not be excluded from the empowerment of their education. For this purpose, the government in the Gulf region has allocated extra allocation money for education (Aubert \& Reiffers, 2004). In this way, the knowledge-based economy will be more dispersed among the people in the gulf region. This will be able to help Arab countries to ensure their sustainable development in the long term. Empirical studies show that the skills can contribute to an increasing in labour productivity and output of production. Indirectly, increases in productivity will help increase economic growth (Baier, Dwyer, \& Tamura, 2006; Korkmaz \& Korkmaz, 2017; Rudolf \& Zurlinden, 2010). Moreover, labour skills are strongly emphasised in the Sustainable Development Goals (SDGs). Therefore, to ensure the Arab countries are willing to blast IR 4.0, they must be willing to equipping people with adequate skillsets. However, the Arab state faced a severe unemployment crisis caused by a mismatch between demand of competencies and skills and those supplied through the education and skills development system (Schwalje, 2014). This situation also led most Arab countries to import expert workers from outside (Ryan, 2016). Since its introduction around the mid-90s, information and communication technology (ICT) has played an essential role in the country's sustainable development. The role of ICT is to enable people, organisations and governments to change information to knowledge. Knowledge, in turn, is an essential element towards achieving more remarkable economic and state development. Extent studies have shown a strong and positive relationship to the use of ICT on economic growth (Cardona, Kretschmer, \& Strobel, 2013; Fernández-Portillo, Almodóvar-González, \& Hernández-Mogollón, 2020; Greenana \& Mairesse, 2000; Nasab \& Aghaei, 2009). However, the magnitude is varied according to the type of technology used (Niebel, 2018). Studies in the Middle East show that ICT significantly impacts economic growth (Bahrini \& Qaffas, 2019; Yazdan \& Hossein, 2013). In addition, Langendorf (2020) also stated that ICT is also a solution to youth unemployment in the region. This clearly shows that technology is a very positive influence on the economic development and social of the Arab region.

In general, innovation always plays a vital role in developing a country (Parcero \& Ryan, 2017). It became a key driver to economic growth and competitiveness (Carayannis, Goletsis, \& Grigoroudis, 2018). Innovation and technological development can help accelerate the development and growth of an economy. Innovation is very closely related to entrepreneurship that helps accelerate the growth of an economy. However, the development of innovations for developing countries somewhat far behind than developed countries (Ismail et al., 2005; Alwi, et al., 2013). This situation also differs considerably for the Arab region countries. The latest study showed that the innovation level for the Arab region country was somewhat far behind developed countries and emerging countries (Barkhordari et al., 2019; Parcero \& Ryan, 2017). This is a great challenge to the Arab region country.

\section{Methodology \\ Data and Variables}

The study used the annual data from the World Bank Data set from 1980 to 2015. The description of the variables is as reported in Table 1. 
Table 1: Data Description

\begin{tabular}{|c|c|c|}
\hline Variable & Description & Source \\
\hline LGDPC & Current Growth domestic product in USD & World Bank \\
\hline LGCFC & Current Gross capital formation in USD. & World Bank \\
\hline LLPRT & Total Labour Force Participation Rate (age 15-64) & World Bank \\
\hline LTRADE & Trade (\% of GDP) & World Bank \\
\hline LENSCN & $\begin{array}{l}\text { Gross secondary enrolment rate to represent a pillar of } \\
\text { education and skill in Knowledge-Based Economy }\end{array}$ & World Bank \\
\hline LTELEFIX & $\begin{array}{l}\text { Telephones for } 1000 \text { people to represent a pillar of } \\
\text { information in Knowledge-Based Economy }\end{array}$ & World Bank \\
\hline LJRNL & $\begin{array}{l}\text { Total Journal articles per } 1 \text { million people to represent a pillar } \\
\text { of innovation in Knowledge-Based Economy }\end{array}$ & World Bank \\
\hline
\end{tabular}

Notes: $L G C F C, L L P R T$, and LTRADE portray production economy (p-economy); LENSCN, LTELEFIX and LRNL represent pillars in the knowledge-based economy.

\section{Method of Analysis}

\section{Panel unit root tests}

Before the cointegration analysis is carried out, we need to ensure that all the data are integrated into the same order. For that purpose, we employed the first-generation tests for panel unit root by Im, Pesaran and Shin (2003) and, Maddala and Wu (1999). Meanwhile, we employed the Pesaran (2007) method for the second-generation test of panel unit root. These two tests are more powerful and less restrictive than the panel unit root developed by Levin, Lin and Chu (2002). The Im et al. (2003) tests allowed for heterogeneity in the autoregressive coefficient. Indirectly these tests can resolve the serial correlation problems. The equation for the panel unit root test for Im et al. (2003) is as follows:

(1)

$$
\Delta y_{i t}=\alpha_{i}+\rho_{i} y_{i, t-1}+\sum_{j=1}^{\rho} \emptyset_{i j} \Delta y_{i, t-j}+\varepsilon_{i, t} ; i=1,2, \ldots, N ; t=1,2, \ldots . T,
$$

where for each variable under consideration, $\alpha_{i}$ stand for the fixed effect and to make the residual uncorrelated over time $\rho$ is chosen. It is that the null hypothesis $\rho_{i}=0$ for all $i$ versus the alternative hypothesis is that $\rho_{i}<0$ for some $i=1, \ldots, N_{1}$ and $\rho_{i}=0$ for $=N_{1}+1, \ldots, N$

Averaging individual ADF statistics are based on the IPF statistics, which can be written as follows:

(2)

$$
\bar{t}=\frac{1}{N} \sum_{i=1}^{N}\left(t_{i T}\right)
$$

The ADF is based on the country-specific ADF regression where $t_{i T}$ is the ADF t-statistics for country $i$, as in Eq (1). The null hypothesis of non-stationary, which is under IPS shows the $\bar{t}$ statistics follow the normal standard distribution asymptotically. Where, $t_{I P S}$, the standardised statistic can be written as:

$$
t_{I P S}=\frac{\sqrt{n}\left(\bar{t}-\frac{1}{N} \sum_{i=1}^{N} E\left[t_{i T} \mid \rho_{i}=0\right]\right)}{\sqrt{\frac{1}{N}} \sum_{i=1}^{N} \operatorname{Var}\left[t_{i T} \mid \rho_{i}=0\right]}
$$


(3)

According to Maddala and Wu (1999), although Im et al.'s tests relax the assumption of homogeneity of the root across the units, while few hardness continues to persist. Maddala and $\mathrm{Wu}(1999)$ recommend the use of a Fischer type test which is based on combining the $p$ values, $\pi_{i}$ of the test statistic for a unit root in every cross-sectional unit. The MW test statistic $\lambda$ is given by:

(4)

$$
\lambda=-2 \sum_{i=1}^{N} \ln \pi_{i}
$$

The MW test statistic is arranged as chi-square with $2 \mathrm{~N}$ degrees of freedom under the hypothesis of cross-sectional independence. It is stated that IPS's test is not powerful when it is included of individual trends, Breitung and Das (2005). This test is sensitive to the specification of deterministic trends as a contrast to IPS's test. It has its own advantages of the MW test which that its value does not depend on different lag length in the individual ADF regressions. Besides, they also found that MW's test is more calibre in comparison to IPS's test.

The test (IPS and MW) each flaw in assuming that the cross-section is independent; the same assumption is made in all first generation of panel unit root. Despite, it has been pointed out in the literature that cross-section dependence emerges due to unobserved common factors, externalities, regional and macroeconomics linkages, and unaccounted residual interdependence. It appears recently that some new panel unit root test has emerged and addressed the question of the dependence and correlation given the prevalence of macroeconomics dynamics and linkages. These tests are called the second generation panel unit root tests. The well-known second-generation test that is considered in this paper is the Pesaran's CIPS test. In order to formulate a panel unit root test with cross-sectional dependence, Pesaran (2007) examine the following Cross-Sectional Augmented Dickey-Fuller (CADF) regression, estimated the OLS method for the $i^{\text {th }}$ cross-section in the panel:

(5)

$$
\Delta y_{i t}=\alpha_{i}+\rho_{i} y_{i, t-1}+\delta_{i} \bar{y}_{t-1}+\sum_{j=0}^{k} \delta_{i j} \Delta \bar{y}_{i, t-j}+\sum_{j=0}^{k} \Delta y_{i, t-j}+\varepsilon_{i t}
$$

where, $\bar{y}_{t-1}=\left(\frac{1}{N}\right) \sum_{i=1}^{N} y_{i, t-1}, \Delta \bar{y}_{t}=\left(\frac{1}{N}\right) \sum_{i=1}^{N} y_{i t}$, and $t_{i}(N, T)$ is the $t$-statistics of the estimate of $\rho_{i}$ as the equation above shown the used for computing the individual ADF statistics. Pesaran also proposed the following test CIPS statistic that is based on the average of individual CADF statistics as follows:

(6)

$$
C I P S=\left(\frac{1}{N}\right) \sum_{i=1}^{N} t_{i}(N, T) .
$$

The critical values for CIPS for various deterministic terms are tabulated by Pesaran (2007).

\section{Panel cointegration tests}

We apply Predroni's cointegration test methodology once the order of stationary has been defined. In a real situation, like the IPS and MW panel unit root, the panel cointegration tests proposed by Pedroni (1999) also consider the heterogeneity by using specific parameters that can vary across individual members of the sample. As a consideration, such heterogeneity 
constitutes an advantage because it is unrealistic to assume that the vectors of cointegration are similar from an individual to another for the panel.

The implementation of Pedroni's cointegration test depends upon estimating the following run relationship:

$$
\begin{aligned}
y_{i t}= & \alpha_{i}+\delta_{i} t+\beta_{1 i} x_{1, i t}+\beta_{2 i} x_{2, i t}+\cdots+\beta_{M i} x_{M, i t}+\varepsilon_{i t} \\
& \text { for } i=1, \ldots, N ; t=1, \ldots, T ; m=1, \ldots, M
\end{aligned}
$$

(7)

where $N$ refers to the numbers of individual members in the panel; $T$ refers to the number of observation over time; $M$ refers to the number of exogenous variables. The structure of the estimated residuals is as followed:

(8)

$$
\hat{\varepsilon}_{i t}=\hat{\rho}_{i} \hat{\varepsilon}_{i t-1}+\hat{u}_{i t} .
$$

Pedroni (1999) has proposed seven different statistics to test panel data cointegration. Out of these seven statistics, four are based on pooling, referred to as the "Within" dimension, and the last three are based on the "Between" dimension. Both kinds of test focus on the null hypothesis of no cointegration. However, the distinction comes from the specification of the alternative hypothesis. For the tests based on "Within", the alternative hypothesis is $\rho_{i}=$ $\rho<1$ for all $i$, while concerning the last three test statistics, which are based on the "Between" dimension, the alternative hypothesis is $\rho_{i}<1$, for all $i$.

Pedroni (1999) has tabulated the finite sample distribution for the seven statistics via Monte Carlo simulations. The calculated statistic tests must be smaller than the tabulated critical value to reject the null hypothesis of the absence of cointegration.

\section{Panel cointegration estimation}

Although Pedroni's methodology allows us to test the presence of cointegration, it could not provide an estimation of the long-run relationship. For the panel framework, in the presence of cointegration, several estimators are proposed, such as Fully Modified OLS (FMOLS) and dynamic OLS (DOLS). However, McCoskey and Kao (1998) analysed the proprieties of the OLS estimator and found that the bias-corrected OLS estimator does not improve over the OLS estimator in general. Thus, the findings suggest that alternatives, such as the FMOLS estimator or the DOLS estimator, maybe more promising in cointegrated panel regressions. Whereas, Kao and Chiang (2000) stated that both the OLS and Fully Modified OLS (FMOLS) exhibit small sample bias and that the DOLS estimator appears to outperform both estimators.

This paper examines three estimators with error correction: Fully Modified OLS (FMOLS) and dynamic OLS (DOLS) empirically examine the validity of the Feldstein-Harioka puzzle in ASEAN countries.

The Fully Modified OLS (FMOLS) and Dynamic OLS (DOLS) estimators The Fully Modified OLS (FMOLS) and Dynamic OLS (DOLS) methodologies are proposed by Kao and Chiang (2000) to estimate the long-run cointegration vector for non-stationary panels. These estimators correct the standard pooled OLS for serial correlation and endogeneity of regressors normally present in the long-run relationship.

We consider the following fixed effect panel regression:

$$
y_{i t}=\alpha_{i}+x_{i t}^{\prime} \beta+u_{i t}, \quad i=1, \ldots, T,
$$

where $y_{i t}$ is a matrix $(1,1), \beta$ is a vector of a slope $(k, 1)$ dimension, $\alpha_{i}$ is an individual fixed 
effect, $\mu_{i t}$ is the area stationary disturbance terms. It is assumed that $x_{i t}(k, 1)$ vector are integrated processes of order one for all $i$, where:

$$
x_{i t}=x_{i t-1}+\varepsilon_{i t} \text {. }
$$

Based on this condition, (Eq. 9) define a system of cointegrated regression with $x_{i t}$. By studying the limiting distribution of FMOLS and DOLS estimators in cointegrated regressions, it shows that they are asymptotically normal (Kao \& Chiang, 2000). The FMOLS estimator is constructed by making corrections for endogeneity and serial correlation to the OLS estimator and is explained as:

$$
\hat{\beta}_{F M}=\left[\sum_{i=1}^{N} \sum_{t=1}^{T}\left(x_{i t}-\bar{x}_{i}\right)^{\prime}\right]^{-1}\left[\sum_{i=1}^{N}\left(\sum_{t=1}^{T}\left(x_{i t}-\bar{x}_{i}\right) \hat{y}_{i t}^{+}+T \hat{\Delta}_{\varepsilon \mu}^{+}\right)\right],
$$

where $\widehat{\Delta}_{\varepsilon \mu}^{+}$the serial correlation is term and $\hat{y}_{i t}^{+}$is the transformed variable of $y_{i t}$ to achieve the endogeneity correction. The serial correlation and the endogeneity can also be corrected by using the DOLS estimator. The DOLS is an extension of Stock and Watson's (1993) estimator. To achieve an unbiased estimator of the long-run parameters, the DOLS estimator uses parametric adjustment to the errors by including the past and the future values of the differenced I(1) regressors. The dynamic OLS estimator is obtained as follows:

$$
y_{i t}=\alpha_{i}+x_{i t}^{\prime} \beta+\sum_{j=-q_{1}}^{j=q_{2}} c_{i j} \Delta x_{i, t+j}+v_{i t} \text {. }
$$

where $c_{i j}$ is the coefficient of a lead or lag first difference explanatory variables. The estimated coefficient of DOLS is given by:

$$
\hat{\beta}_{D O L S}=\sum_{i=1}^{N}\left(\sum_{t=1}^{T} z_{i t} z^{\prime}{ }_{i t}\right)^{-1}\left(\sum_{t=1}^{T} z_{i t} \hat{y}_{i t}^{+}\right)
$$

Where $z_{i t}=\left[x_{i t}-\bar{x}_{i}, \Delta x_{i, t-q}, \ldots, x_{i, t+q}\right]$ is $2(q+1) \times 1$ vector of regressors.

\section{Results}

\section{The Unit Root Tests}

Table 2 reports the outcome for the Gulf countries of panel unit root tests for three models: unit root model with individual intercept, individual intercept and trend, and none. It shows that the null hypothesis of the unit-roots for the panel data for the knowledgebased economy. From this empirical panel unit roots tests, we found that the hypothesis is rejected when series are in first differences. Therefore, we can implement a test for panel cointegration between economic growth and knowledge-based economy factors.

\section{Panel Cointegration Tests}

Table 3 shows the outcomes of Pedroni's (1999) cointegration tests between economic growth and knowledge-based economy factors. We use within-group and between-group tests to check whether the panel data are cointegrated. The columns labelled withindimension contain the computed value of the statistics based on estimators that pool the autoregressive coefficient across different countries for the unit root tests on the estimated 
residuals. The columns labelled between-dimension report the computed value of the statistics based on estimators that average individually estimated coefficients for each country. Therefore, the ratios between economic growth and knowledge-based economy factors are cointegrated for the panel of all Muslim Gulf Countries.

A long-run relationship between economic growth and knowledge-based economy factors is economically meaningful in that it suggests that Arabic Gulf Countries meet the long-run solvency condition. There is an existence of a cointegrating link between variables, it is convenient that economic growth and knowledge-based economy factors coefficient be estimated using a panel cointegrating estimator. In this paper, we choose to employ several panel cointegrating estimators such as Fully Modified OLS (FMOLS), the Dynamic OLS (DOLS) and the Pooled Mean Group (PMG). 
Table 2: Panel unit root for Gulf Countries, 1980-2015

\begin{tabular}{|c|c|c|c|c|c|c|c|c|c|c|c|c|}
\hline & Indiv & ual Ir & ept & & $\begin{array}{l}\text { Indivic } \\
\text { Trend }\end{array}$ & al & tercept & & None & & & \\
\hline & $\begin{array}{l}\text { Levin } \\
\text { et al }\end{array}$ & $\begin{array}{l}\text { Im } \\
\text { et. al }\end{array}$ & $\begin{array}{l}\text { Pesa } \\
\text { ran } \\
\text { (ADF } \\
\text { ) }\end{array}$ & PP & $\begin{array}{l}\text { Levi } \\
n \text { et } \\
\text { al }\end{array}$ & $\begin{array}{l}\text { Breit } \\
\text { ung }\end{array}$ & $\begin{array}{l}\text { Im } \\
\text { et. al }\end{array}$ & $\begin{array}{l}\text { Pesa } \\
\text { ran }\end{array}$ & PP & $\begin{array}{l}\text { Levi } \\
\mathrm{n} \text { et } \\
\text { al }\end{array}$ & $\begin{array}{l}\text { Pesa } \\
\text { ran } \\
\text { (ADF } \\
\text { ) }\end{array}$ & PP \\
\hline & Stat & Stat & Stat & Stat & Stat & Stat & Stat & Stat & Stat & Stat & Stat & Stat \\
\hline$L G D$ & 2.27 & 4.43 & 1.15 & 0.92 & - & 1.67 & - & 18.2 & 9.96 & 4.95 & 0.47 & 0.30 \\
\hline$P C$ & 1 & 2 & 1 & 9 & $\begin{array}{c}2.86 \\
1^{*}\end{array}$ & 9 & $\begin{array}{c}0.84 \\
1\end{array}$ & 92 & 1 & 9 & 2 & 4 \\
\hline$D L G$ & - & - & 55.4 & 99.9 & 1.16 & - & - & 39.0 & 80.9 & - & 65.8 & 117. \\
\hline$D P C$ & $\begin{array}{l}1.10 \\
8\end{array}$ & $\begin{array}{c}5.05 \\
1^{*}\end{array}$ & $5^{*}$ & $23^{*}$ & 9 & $\begin{array}{r}1.60 \\
1^{* * *}\end{array}$ & $\begin{array}{c}3.19 \\
6^{*}\end{array}$ & $26 *$ & $41^{*}$ & $\begin{array}{c}6.75 \\
9 *\end{array}$ & $92 *$ & $128 *$ \\
\hline$L G C F$ & 0.82 & 2.77 & 2.45 & 3.68 & - & - & 0.15 & 10.4 & 13.0 & 3.16 & 0.76 & 0.54 \\
\hline$C$ & 1 & 4 & 0 & 8 & $\begin{array}{c}0.77 \\
0\end{array}$ & $\begin{array}{c}0.03 \\
0\end{array}$ & 3 & 35 & 01 & 1 & 4 & 1 \\
\hline$D L G$ & - & - & 55.0 & 102. & - & - & - & 43.0 & 86.1 & - & 70.4 & 131. \\
\hline CFC & $\begin{array}{c}4.51 \\
0^{*}\end{array}$ & $\begin{array}{c}5.32 \\
1^{*}\end{array}$ & $75^{*}$ & $595^{*}$ & $\begin{array}{c}3.83 \\
3^{*}\end{array}$ & $\begin{array}{c}5.13 \\
6^{*}\end{array}$ & $\begin{array}{c}3.55 \\
2^{*}\end{array}$ & $41^{*}$ & $57^{*}$ & $\begin{array}{c}6.81 \\
9 *\end{array}$ & $11^{*}$ & $319 *$ \\
\hline LTRA & - & - & 24.2 & 27.1 & - & - & - & 22.2 & 16.3 & - & 14.1 & 13.9 \\
\hline$D E$ & $\begin{array}{c}2.75 \\
0 * *\end{array}$ & $\begin{array}{r}2.07 \\
0 * *\end{array}$ & $87^{* *}$ & $40 * *$ & $\begin{array}{r}2.20 \\
8^{* *}\end{array}$ & $\begin{array}{c}1.03 \\
3\end{array}$ & $\begin{array}{r}1.69 \\
2 * *\end{array}$ & 16 & 78 & $\begin{array}{c}0.76 \\
6\end{array}$ & 10 & 14 \\
\hline DLTR & - & - & 86.0 & 122. & - & - & - & 74.5 & 359. & - & 117. & 236. \\
\hline$A D E$ & $\begin{array}{c}7.29 \\
4^{*}\end{array}$ & $\begin{array}{c}7.88 \\
4^{*}\end{array}$ & $48^{*}$ & $309 *$ & $\begin{array}{c}6.85 \\
1^{*}\end{array}$ & $\begin{array}{c}4.12 \\
8 *\end{array}$ & $\begin{array}{c}7.54 \\
9 *\end{array}$ & $75^{*}$ & $687^{*}$ & $\begin{array}{l}10.1 \\
21^{*}\end{array}$ & $173^{*}$ & $379 *$ \\
\hline LTM & $\begin{array}{c}4.25 \\
8\end{array}$ & $\begin{array}{c}1.99 \\
0\end{array}$ & $\begin{array}{c}1.54 \\
1\end{array}$ & $\begin{array}{l}23.5 \\
19 * *\end{array}$ & $\begin{array}{l}20.2 \\
19\end{array}$ & $\begin{array}{c}- \\
0.61 \\
1\end{array}$ & $\begin{array}{c}- \\
0.46 \\
4\end{array}$ & $\begin{array}{l}12.1 \\
39\end{array}$ & $\begin{array}{l}53.4 \\
75^{*}\end{array}$ & $\begin{array}{c}2.45 \\
8\end{array}$ & $\begin{array}{c}1.23 \\
1\end{array}$ & $\begin{array}{c}3.60 \\
8\end{array}$ \\
\hline$D L T$ & 14.1 & - & 69.6 & 46.8 & - & - & - & 37.3 & 306. & - & 51.4 & 112. \\
\hline$M$ & 80 & $\begin{array}{c}7.04 \\
2^{*}\end{array}$ & $38 *$ & $87 *$ & $\begin{array}{l}32.5 \\
61\end{array}$ & $\begin{array}{r}3.02 \\
8 * *\end{array}$ & $\begin{array}{l}10.3 \\
16^{*}\end{array}$ & $27^{*}$ & $156^{*}$ & $\begin{array}{c}7.08 \\
0 *\end{array}$ & $32 *$ & $218^{*}$ \\
\hline LENS & - & - & 23.6 & 79.9 & - & 0.30 & - & 13.1 & 21.0 & 5.42 & 0.40 & 0.02 \\
\hline$C N$ & $\begin{array}{c}4.71 \\
1^{*}\end{array}$ & $\begin{array}{r}2.11 \\
9 * *\end{array}$ & $67 * *$ & $57^{*}$ & $\begin{array}{r}2.89 \\
7 * *\end{array}$ & 0 & $\begin{array}{c}0.49 \\
5\end{array}$ & 40 & 39 & 5 & 0 & 0 \\
\hline$D L E$ & - & - & 57.6 & 68.6 & - & - & - & 43.3 & 59.0 & - & 41.3 & 48.3 \\
\hline NSC & 6.33 & 5.82 & $25^{*}$ & $73 *$ & 4.90 & 0.04 & 2.41 & $46^{*}$ & $50 *$ & 4.62 & $32 *$ & $81^{*}$ \\
\hline$N$ & $5 *$ & $5 *$ & & & $2^{*}$ & 4 & $2 * *$ & & & $5^{*}$ & & \\
\hline$L J R N$ & - & 1.36 & 20.2 & 13.7 & - & 0.70 & - & 56.5 & 10.5 & 4.48 & 0.94 & 0.65 \\
\hline$L$ & $\begin{array}{c}1.46 \\
8\end{array}$ & 8 & 12 & 82 & $\begin{array}{c}4.84 \\
9 *\end{array}$ & 4 & $\begin{array}{r}2.51 \\
7^{* *}\end{array}$ & $42 *$ & 94 & 1 & 1 & 1 \\
\hline$D L J R$ & - & - & 90.1 & 114. & - & - & - & 78.3 & 109. & - & 105. & 124. \\
\hline$N L$ & $\begin{array}{c}9.93 \\
2^{*}\end{array}$ & $\begin{array}{c}8.63 \\
8^{*}\end{array}$ & 99* & $953 *$ & $\begin{array}{c}7.64 \\
7 *\end{array}$ & $\begin{array}{c}4.64 \\
8^{*}\end{array}$ & $\begin{array}{c}7.89 \\
7^{*}\end{array}$ & $54 *$ & $541^{*}$ & $\begin{array}{l}10.3 \\
93 *\end{array}$ & $164^{*}$ & $550 *$ \\
\hline
\end{tabular}


INTERNATIONAL JOURNAL OF ACADEMIC RESEARCH ECONOMICS AND MANAGEMENT SCIENCES Vol. 10, No. 3, 2020, E-ISSN: 2226-3624 @ 2020 HRMARS

\begin{tabular}{ccccccccccccc} 
LLF & - & 2.11 & 11.4 & 0.40 & - & - & - & 55.4 & 3.16 & 2.90 & 2.60 & 0.00 \\
& 1.29 & 6 & 60 & 0 & 7.45 & 0.02 & 5.03 & $08^{*}$ & 4 & 8 & 9 & 6 \\
& 6 & & & & $3^{*}$ & 0 & $5^{*}$ & & & & & \\
\multirow{2}{*}{ LLF } & - & - & 24.6 & 13.8 & - & - & - & 16.4 & 7.65 & - & 21.3 & 12.2 \\
& 2.68 & 1.95 & $42^{* *}$ & 03 & 1.55 & 1.86 & 0.54 & 03 & 6 & 2.04 & $27^{* *}$ & 47 \\
& $5^{* *}$ & $1 * *$ & & & $8^{* * *}$ & $4^{* *}$ & 8 & & & $1^{* *}$ & $*$ & \\
\hline
\end{tabular}

Note: $* * *, * * *$ mean significant at $10 \%, 5 \%$ and $1 \%$ respectively.

Table 3: Pedroni Panel cointegration test results, $1980-2015$

\begin{tabular}{|c|c|c|}
\hline \multicolumn{3}{|c|}{ Within-dimension (panel) } \\
\hline Test & Statistic & $\begin{array}{l}\text { Weighted } \\
\text { Statistic }\end{array}$ \\
\hline$v$-Stat & -1.5764 & -1.8414 \\
\hline$\rho$-Stat & 1.0966 & 0.9803 \\
\hline PP-Stat & $-5.6153^{*}$ & $-6.6383^{*}$ \\
\hline ADF-Stat & $-2.8730 * *$ & $-3.4282 * *$ \\
\hline \multicolumn{3}{|c|}{ Between-dimension (group) } \\
\hline rho-Stat & 2.0838 & \\
\hline PP-Stat & $-6.3138^{*}$ & \\
\hline ADF-Stat & $-1.6754 * *$ & \\
\hline
\end{tabular}

Notes: Results with a trend and time-dummies. The test statistics are normalised so that the asymptotic distribution is standard normal. *,**, *** indicate rejection of the null hypothesis of non-cointegration at the 10,5 , and 1 per cent significance levels.

\section{Panel Cointegration Estimations}

We estimate the cointegrating vector using three methods: FMOLS, DOLS and PMG estimators. Table 4 shows the regression result of the factors influencing the economic growth in Muslim Gulf countries for FMOLS, DOLS and OLS. The empirical result shows that the result is mixed between all models. Results of FMOLS indicate that $1 \%$ increase in capital, labour participation, education and innovation as a percentage of GDP increases by about $0.50 \%, 1.92 \%, 0.32 \%$ and $0.24 \%$, respectively in the Muslim Gulf Countries. Both OLS and FMOLS estimators exhibit a small sample bias; however, the estimators by DOLS seems to outperform the preceding models (Kao $\&$ Chiang, 2000). Kao and Chiang (2000) have discussed the advantages of DOLS estimators. To avoid such a tendency in our analysis, we have further applied the DOLS estimator to gauge the long-run relation. The DOLS result indicates that trade is significant to determine economic growth. The result also indicated that all of the three knowledge-based economies' criteria, namely education, information and innovation, significantly influence the economic growth in the Gulf Countries. The final step in implementing an alternative methodology consists of the PMG approach proposed by Pesaran, Shin and Smith (1999). The PMG empirical result indicates that all factors are significant to determine economic growth in the Gulf Countries except trade and innovation. 
We found that only the education's factor influences the Gulf economic growth for all three models for the knowledge-based economy factors. This shows that education plays an important role in improving economic growth in the Gulf region. However, the coefficient for education is very small for these three models. The study also found that innovation is very important in influencing the economic growth of the Gulf region. As well as education, the innovation coefficient is low in influencing the economic growth of the Gulf region. The study also shows that information is very significant in influencing economic growth. Nevertheless, information has a negative relationship with economic growth. It shows that people in the Gulf region mostly are consumers of technology and not those who take the benefits of information for income generation.

Table 4: Pedroni Panel cointegration test results, 1981 - 2015

\begin{tabular}{lcclccc}
\hline Variables & \multicolumn{1}{l}{$\begin{array}{l}\text { FMOLS } \\
\text { Coeff }\end{array}$} & \multicolumn{1}{c}{ t-stat } & \multicolumn{1}{l}{ Coeff } & \multicolumn{1}{l}{ t-stat } & \multicolumn{1}{l}{ Coeff } & t-stat \\
\hline LGCFC & $0.505^{*}$ & 8.040 & -0.159 & -1.731 & $0.450^{* *}$ & 3.147 \\
LLPRT & $1.927^{*}$ & 5.349 & -0.640 & -1.537 & $2.345^{* *}$ & 3.007 \\
LENSCN & $0.321^{*}$ & 8.331 & $2.783^{*}$ & 14.969 & $0.574^{* *}$ & 3.223 \\
LTRADE & -0.040 & -0.389 & $1.694^{* *}$ & 10.651 & -0.332 & -0.767 \\
LTELFIX & -0.097 & -1.059 & $-2.519 *$ & -13.588 & $-0.564^{* *}$ & -2.101 \\
LJRNL & $0.247^{*}$ & 4.113 & $0.132^{* *}$ & 2.711 & 0.011 & 0.067 \\
$\mathrm{R}^{2}$ & 0.976 & & 0.999 & & & \\
Adj R & 0.974 & & 0.997 & & $-0.121^{* *}$ & \\
\hline
\end{tabular}

Note: ${ }^{*},{ }^{*}$ denote statistical significance at the 5 per cent and 1 per cent levels, respectively.

\section{Conclusion}

Knowledge-based economy is a new economic processing system on production, consumption, marketing and distribution based on knowledge, information, and technology. The knowledgebased economy was also found to increase the sum of investment through changes in the quantity and quality of delivery (Amin et al, 2013). Therefore, Arab Gulf countries wish to transform their production economy into a knowledge economy. Aware of this fact, this paper attempts to investigate the contribution of the knowledge-based economy to Arab Gulf countries' economic growth.

In this study, capital and labour are used as control variables. Both variables are proxies to the production economy. Meanwhile, we employed gross secondary enrollment to represent a pillar of education and skill for the knowledge economy. To represent a pillar of information infrastructure, we employed a total of telephones per 1000 people. Meanwhile, for a pillar of innovation, we employed the total of technical journal article per 1 million people.

Our empirical results indicated that a knowledge-based economy plays a vital role in economic growth in the gulf region. In general, this study found that three knowledge-based economy criteria, education, information and communication technology (ICT) and innovation, significantly influence Arabic Gulf countries' economic growth. We found that the education's factor influences the Gulf economic growth for all three models for the knowledge-based economy factors. This shows that education plays an important role in improving economic growth in the Gulf region. The study also found that innovation is very important in influencing 
the economic growth of the Gulf region. Like education, the innovation coefficient is low in influencing the economic growth of the Gulf region. In contrast, information has a negative relationship with economic growth. This shows that people in the Gulf region mostly are consumers of technology and not those who take the benefits of information for income generation.In order to be more competitive, the gulf countries have successfully channeled existinghuman resources towards a knowledge-based economy. The education system have proven to create a community that can support the use of technology. Increasing human capital quality can maximise the proficiency of a knowledge-based economy. However, more effort should be carried out to increase the quality and level of education in the gulf countries. In addition, to compete globally, research and innovation should be in line with advances in technology and human resource development. First, increasing the quality of the education system pertaining to human resource development will produce a highly skilled workforce, which will help reduce the reliance on skilled foreign workers. Second, the government should ensure their citizens become hardcore users of ICT and encourage them to be content developers. Third, more attempts should be done to increase the usage of information in generating income to boost the economy. The government and corporate sectors in the gulf countries could probably invest in big data and clouds to make use of available information.

Overall, this study provide theoretical implications and some insights relating to the knowledge economy pillars and the economic growth. Other researchers should be able to conduct more studies to understand how knowledge economy pillars can influence the economic growth in Arab Gulf Countries. The results obtained will be able to help the Arab Gulf Countries to devise their knowledge economy strategies. The findings of this study also give practical implications for the regulators in the Gulf countries as input for their effort to create an economic environment conducive to enhancing the level of knowledge and, hence, economic growth.

\section{References}

Abu-Qarn, A. S., \& Abu-Bader, S. (2007). Sources of growth revisited: Evidence from selected MENA countries. World Development, 35(5), 752-771.

Acikgoz, S., \& Ben Ali, M. S. (2019). Where does economic growth in the Middle Eastern and North African countries come from? The Quarterly Review of Economics and Finance, 73, 172183. https://doi.org/10.1016/j.qref.2019.03.007

Afzal, M., Rehman, H. U., Farooq, M. S., \& Sarwar, K. (2011). Education and economic growth in Pakistan: A cointegration and causality analysis. International Journal of Educational Research, 50(5-6), 321-335. https://doi.org/10.1016/j.ijer.2011.10.004

Alwi, M., Ismail, W. A., \& Kamarudin, K. A. (2013). The effectiveness of audit committee in relation to financial reporting fraud. In Proceeding of The 5th International Conference on Financial Criminology (ICFC), 332-344.

Amin, J. M., Saringat, S. M., Hassan, H., and Ismail, W. A. W. (2013). Intellectual capital disclosure in Malaysian public listed companies, IEEE Business Engineering and Industrial Applications Colloquium, Art. No. 6560223, 703-708.

Asongu, S. A., \& Andrés, A. R. (2020). Trajectories of knowledge economy in SSA and MENA countries. Technology in Society, 63, 101119.

https://doi.org/10.1016/j.techsoc.2019.03.002

Asongu, S. A., \& Kuada, J. (2020). Building knowledge economies in Africa: an introduction. 
INTERNATIONAL JOURNAL OF ACADEMIC RESEARCH ECONOMICS AND MANAGEMENT SCIENCES

Vol. 10, No. 3, 2020, E-ISSN: 2226-3624 @ 2020 HRMARS

Contemporary Social Science, 15(1), 1-6. https://doi.org/10.1080/21582041.2020.1722213 Aubert, J.-E., \& Reiffers, J.-L. (2004). Knowledge Economies in the Middle East and North Africa: Toward New Development Strategies. Washington, DC: World Bank.

Bahrini, R., \& Qaffas, A. A. (2019). Impact of information and communication technology on economic growth: Evidence from developing countries. Economies, 7(1). https://doi.org/10.3390/economies7010021

Baier, S. L., Dwyer, G. P., \& Tamura, R. (2006). How important are capital and total factor productivity for economic growth? Economic Inquiry, 44(1), 23-49.

https://doi.org/10.1093/ei/cbj003

Barkhordari, S., Fattahi, M., \& Azimi, N. A. (2019). The Impact of Knowledge-Based Economy on Growth Performance: Evidence from MENA Countries. Journal of the Knowledge Economy, 10(3), 1168-1182. https://doi.org/10.1007/s13132-018-0522-4

Ben Hassen, T. (2020). The state of the knowledge-based economy in the Arab world: cases of Qatar and Lebanon. EuroMed Journal of Business, (Forthcoming). https://doi.org/10.1108/EMJB-03-2020-0026

Booth, L., Aivazian, V., Demirguc-Kunt, A., \& Maksimovic, V. (2001). Capital structures in developing countries. Journal of Finance, 56(1), 87-130. https://doi.org/10.1111/00221082.00320

Breitung, J., \& Das, S. (2005). Panel unit root tests under cross-sectional dependence. Statistica Neerlandica, 59(4), 414-433. https://doi.org/10.1111/j.1467-9574.2005.00299.x

Carayannis, E. G., Goletsis, Y., \& Grigoroudis, E. (2018). Composite innovation metrics: MCDA and the Quadruple Innovation Helix framework. Technological Forecasting and Social Change, 131, 4-17. https://doi.org/10.1016/j.techfore.2017.03.008

Cardona, M., Kretschmer, T., \& Strobel, T. (2013). ICT and productivity: Conclusions from the empirical literature. Information Economics and Policy, 25(3), 109-125.

https://doi.org/10.1016/j.infoecopol.2012.12.002

Carrillo, F. J. (2015). Knowledge-based development as a new economic culture. Journal of Open Innovation: Technology, Market, and Complexity, 1(2). https://doi.org/10.1186/s40852015-0017-5

El-Khoury, G. (2015). Knowledge in Arab countries: selected indicators. Contemporary Arab Affairs, 8(3), 456-468. https://doi.org/10.1080/17550912.2015.1054117

Fernández-Portillo, A., Almodóvar-González, M., \& Hernández-Mogollón, R. (2020). Impact of ICT development on economic growth. A study of OECD European union countries. Technology in Society, 63(April), 101420. https://doi.org/10.1016/j.techsoc.2020.101420

Greenana, N., \& Mairesse, J. (2000). Computers And Productivity In France: Some Evidence. Economics of Innovation and New Technology, 9(3), 275-315.

https://doi.org/10.1080/10438590000000011

Huarng, K. H., Rey-Martí, A., \& Guaita-Martínez, J. M. (2020). Knowledge, business, and innovation: Economies and sustainability of future growth. Journal of Business Research, 112(March), 236-239. https://doi.org/10.1016/j.jbusres.2020.03.022

Hvidt, M. (2015). The State and the Knowledge Economy in the Gulf: Structural and Motivational Challenges. The Muslim World, 105(1), 24-45. https://doi.org/10.1111/muwo.12078

Im, K. S., Pesaran, M. H., \& Shin, Y. (2003). Testing for unit roots in heterogeneous panels. Journal of Econometrics, 115(1), 53-74. https://doi.org/10.1016/S0304-4076(03)00092-7 
Ismail, W.A.W., Raja Ahmad, R. A., Kamarudin, K. A., Yahaya, R. 2005. Corporate Failure Prediction: An Investigation of PN4 Companies. Journal of Financial Reporting and Accounting, 3 (1), 1-16.

Kao, C., \& Chiang, M.-H. (2000). On the estimation and inference of a cointegrated regression in panel data. In Advances in Econometrics (Vol. 15, pp. 179-222). https://doi.org/10.1016/S0731-9053(00)15007-8

Kamarudin, K.A., Ismail, W.A.W. and Samsuddin, M.E. (2012), "The role of the audit committee in moderating the negative effect of Non-Audit services on earnings quality", 2nd International Conference on Management, Holiday Villa Beach Resort and Spa, Langkawi Kedah.

Korkmaz, S., \& Korkmaz, O. (2017). The Relationship between Labor Productivity and Economic Growth in OECD Countries. International Journal of Economics and Finance, 9(5), 71. https://doi.org/10.5539/ijef.v9n5p71

Langendorf, M. (2020). Digital Stability: How technology can empower future generations in the Middle East. European Council on Foreign Relations. Retrieved from European Council on Foreign Relations website: http://www.jstor.org/stable/resrep24718

Levin, A., Lin, C. F., \& Chu, C. S. J. (2002). Unit root tests in panel data: Asymptotic and finitesample properties. Journal of Econometrics, 108(1), 1-24. https://doi.org/10.1016/S03044076(01)00098-7

Maddala, G. S., \& Wu, S. (1999). A Comparative Study of Unit Root Tests with Panel Data and a new simple test. Oxford Bulletin of Economics and Statistics, 61, 631-652.

Mahmud, M. (2003). The relationship between economic growth and capital structure of listed companies: Evidence of Japan, Malaysia, and Pakistan. Pakistan Development Review, 42 (4 II), 727-748. https://doi.org/10.30541/v42i4iipp.727-750

Malik, M., \& Masood, T. (2021). Economic Growth, Productivity, and Convergence of Middle East and North Africa Countries. Journal of Economic Cooperation and Development, 41(4), 125.

Marquez-Ramos, L., \& Mourelle, E. (2019). Education and economic growth: an empirical analysis of nonlinearities. Applied Economic Analysis, 27(79), 21-45. https://doi.org/10.1108/AEA06-2019-0005

McCoskey, S., \& Kao, C. (1998). A residual-based test of the null of cointegration in panel data. Econometric Reviews, 17(1), 57-84. https://doi.org/10.1080/07474939808800403

Mokhova, N., \& Zinecker, M. (2014). Macroeconomic Factors and Corporate Capital Structure. Procedia - Social and Behavioral Sciences, 110, 530-540.

https://doi.org/10.1016/j.sbspro.2013.12.897

Nasab, E. H., \& Aghaei, M. (2009). The Effect of ICT on Economic Growth in Nigeria. International Bulletin of Business Administration, 5, 46-56.

Niebel, T. (2018). ICT and economic growth - Comparing developing, emerging and developed countries. World Development, 104, 197-211.

https://doi.org/10.1016/j.worlddev.2017.11.024

Nour, S. (2019). Knowledge economy and economic development in the Arab region. In United Nations University, UNU-MERITS Working Paper Series. Retrieved from http://www.merit.unu.edu/publications/wppdf/2019/wp2019-009.pdf

Ogundeinde, A., \& Ejohwomu, O. (2016). Knowledge Economy: A Panacea for Sustainable 
INTERNATIONAL JOURNAL OF ACADEMIC RESEARCH ECONOMICS AND MANAGEMENT SCIENCES

Vol. 10, No. 3, 2020, E-ISSN: 2226-3624 @ 2020 HRMARS

Development in Nigeria. Procedia Engineering, 145, 790-795.

https://doi.org/10.1016/j.proeng.2016.04.103

Parcero, O. J., \& Ryan, J. C. (2017). Becoming a Knowledge Economy: the Case of Qatar, UAE, and 17 Benchmark Countries. Journal of the Knowledge Economy, 8(4), 1146-1173. https://doi.org/10.1007/s13132-016-0355-y

Pedroni, P. (1999). Critical Values for Cointegration Tests in Heterogeneous Panels with Multiple Regressors. Oxford Bulletin of Economics and Statistics, 61(s1), 653-670.

https://doi.org/10.1111/1468-0084.0610s1653

Pesaran, M. H. (2007). A simple panel unit root test in the presence of cross-section dependence. Journal of Applied Econometrics, 22(2), 265-312. https://doi.org/10.1002/jae.951

Pesaran, M. H., Shin, Y., \& Smith, R. P. (1999). Pooled Mean Group Estimation of Dynamic Heterogeneous Panels. Journal of the American Statistical Association, 94(446), 621-634. https://doi.org/10.1080/01621459.1999.10474156

Rezny, L., White, J. B., \& Maresova, P. (2019). The knowledge economy: Key to sustainable development? Structural Change and Economic Dynamics, 51, 291-300. https://doi.org/10.1016/j.strueco.2019.02.003

Rudolf, B., \& Zurlinden, M. (2010). Productivity and economic growth in Switzerland 1991-2006. Swiss Journal of Economics and Statistics, 146(3), 577-600.

https://doi.org/10.1007/BF03399328

Ryan, J. C. (2016). Old knowledge for new impacts: Equity theory and workforce nationalization. Journal of Business Research, 69(5), 1587-1592.

https://doi.org/10.1016/j.jbusres.2015.10.022

Ryan, J. C., \& Daly, T. M. (2019). Barriers to innovation and knowledge generation: The challenges of conducting business and social research in an emerging country context. Journal of Innovation and Knowledge, 4(1), 47-54. https://doi.org/10.1016/j.jik.2017.10.004

Schwalje, W. (2014). Knowledge-based economic development as a unifying vision in a postawakening Arab World. International Journal of Human Resources Development and Management, 14(1/2/3), 47. https://doi.org/10.1504/IJHRDM.2014.068073

Self, S., \& Grabowski, R. (2004). Does education at all levels cause growth? India, a case study. Economics of Education Review, 23(1), 47-55. https://doi.org/10.1016/S02727757(03)00045-1

Stock, J. H., \& Watson, M. W. (1993). A Simple Estimator of Cointegrating Vectors in Higher Order Integrated Systems. Econometrica, 61(4), 783. https://doi.org/10.2307/2951763

Tamtana, J. S. (2007). The future of knowledge management. Management Learning, 38(1), 125126. https://doi.org/10.1177/135050760703800109

Todaro, M. P., \& Smith, S. C. (2006). Economic development. Harlow: Pearson Education Ltd.

Volkov, D., \& Garanina, T. (2007). Intangible assets: Importance in the knowledge-based economy. Electronic Journal of Knowledge Management, 5(4), 539-550.

Ismail, W. A., Kamarudin, K. A., \& Othman, R. (2012). Assessment of Earnings Conservatism in Government-Linked Companies. Procedia - Social and Behavioral Sciences, 65, 650-655.

Weber, A. S. (2011). The role of education in knowledge economies in developing countries. Procedia - Social and Behavioral Sciences, 15, 2589-2594.

https://doi.org/10.1016/j.sbspro.2011.04.151

World Bank. (2015). World Development Report 2015: Mind Society and Behavior. DC: 
INTERNATIONAL JOURNAL OF ACADEMIC RESEARCH ECONOMICS AND MANAGEMENT SCIENCES Vol. 10 , No. 3, 2020, E-ISSN: 2226-3624 ㄷ 2020 HRMARS

Washington.

Yazdan, G. F., \& Hossein, S. S. M. (2013). FDI and ICT Effects on Productivity Growth. Procedia Social and Behavioral Sciences, 93, 1710-1715. https://doi.org/10.1016/j.sbspro.2013.10.104

Yigitcanlar, T., Guaralda, M., Taboada, M., \& Pancholi, S. (2016). Place Making for Knowledge Generation and Innovation: Planning and Branding Brisbane's Knowledge Community Precincts. Journal of Urban Technology, 23(1), 115-146.

https://doi.org/10.1080/10630732.2015.1090198 